Instructions for authors, subscriptions and further details:

http://rise.hipatiapress.com

\title{
New Institutionalism in Everyday Life
}

Andrea Jean Bingham ${ }^{1}$

1) University of Colorado, United States

Date of publication: October $25^{\text {th }}, 2018$

Edition period: October 2018-February 2019

To cite this article: Bingham, A.J. (2018). New Institutionalism in Everyday Life, International Journal of Sociology of Education, 7(3), 237-255. doi: 10.17583/rise.2018.3532

To link this article: http://dx.doi.org/10.17583/rise.2018.3532

\section{PLEASE SCROLL DOWN FOR ARTICLE}

The terms and conditions of use are related to the Open Journal System and to Creative Commons Attribution License (CC-BY) 


\section{New Institutionalism in Everyday Life}

Andrea Jean Bingham

University of Colorado

(Received: 4 June 2018; Accepted: 17 September 2018; Published: 25

October 2018)

\section{Abstract}

In this paper, I examine how new institutionalism is similar to, and may expand upon Goffman's dramaturgical analysis of human action and social life. I argue that while Goffman's dramaturgical lens is useful for examining micro-social interactions among individuals, the 'audience,' and the organization, integrating new institutionalism as a theoretical framework into Goffman's framework of dramaturgical analysis may provide the tools for combined micro-/macro-social analysis that incorporates the overarching influence of the institution (the 'theater') on micro-social interactions. I examine the potential of combining new institutionalism with dramaturgical analysis and I provide a brief example using 'education' as the institution to demonstrate how new institutional theory may be used in conjunction with Goffman's dramaturgical theory.

Keywords: institutional theory, dramaturgical analysis, sociology of education 


\section{Nuevo Institucionalismo en la Vida Cotidiana}

Andrea Jean Bingham

University of Colorado

(Recibido: 4 Junio 2018; Aceptado: 17 Septiembre 2018; Publicado: 25

Octubre 2018)

\section{Resumen}

En este trabajo, examino cómo el nuevo institucionalismo es similar y puede ampliar el análisis dramatúrgico de Goffman de la acción humana y la vida social. Argumento que si bien la lente dramatúrgica de Goffman es útil para examinar las interacciones micro sociales entre los individuos, la "audiencia" y la organización, integrando el nuevo institucionalismo como marco teórico en el marco del análisis dramatúrgico de Goffman pueden proporcionar las herramientas para combinar micro / macro -el análisis social que incorpora la influencia general de la institución (el "teatro") en las interacciones micro-sociales. Examino el potencial de combinar la nueva institucionalidad con el análisis dramatúrgico y proporciono un breve ejemplo usando la 'educación' como la institución para demostrar cómo la nueva teoría institucional puede ser utilizada junto con la teoría dramatúrgica de Goffman.

Palabras clave: teoría institucional, análisis dramatúrgico, sociología de la educación 
n 1959, The Presentation of Self in Everyday Life was published (Goffman, 1959). In this seminal work, Erving Goffman developed and presented an analysis of social interaction from the perspective of a theatrical performance. Writing during the heyday of Fordism, Goffman aimed to identify and classify behaviors at a time during which he assumed people knew their place in the world and the behaviors expected of them in different situations. Further, he was able to recognize that people conveyed certain images depending on the audience for their performance. These micro-social interactions fit neatly into Goffman's analysis of everyday life.

Almost 60 years later, Goffman's analysis is still useful in analyzing micro-social interactions within a defined context. However, though Goffman's study of the performance of social interaction is still applicable to those micro-social interactions, Goffman did not write much about the role of the institution in his analysis. He included the audience and organizations as influencing factors, but did not expand his analysis to include the structures within which the actors and organizations operate. I argue that incorporating another theoretical layer into Goffman's theory- the lens of new institutionalism (e.g. March \& Olsen, 1983; DiMaggio \& Powell, 1991; Powell \& DiMaggio, 2012; Selznick, 1996) - a perspective that is markedly similar to Goffman's micro-social examination, but offers the benefit of a more macro-social perspective.

My purpose here is to examine how new institutionalism is similar to, and may expand upon Goffman's dramaturgical analysis of human action and social life. In so doing, I use the discipline of education as an example to explore how the integration of these two theories may be used in educational research. In pursuit of this goal, I first outline the main points of Goffman's theory. I then examine new institutionalism, focusing on the sociological approach to institutions and their role in organizational analysis. Finally, I explore how new institutional theory may be used in conjunction with Goffman's dramaturgical theory and provide a brief example using 'education' as the institution. I conclude with a discussion of how integrating neo-institutionalism into Goffman's dramaturgical analysis may further illuminate the connections between individual and organizational behavior. 


\section{The Presentation of Self in Everyday Life}

In The Presentation of Self in Everyday Life, Goffman (1959) employs the perspective of a theatrical performance, and uses dramaturgical principles to analyze social interaction. Goffman's purpose is to

consider the way in which the individual in ordinary work situations presents himself and his activity to others, the ways in which he guides and controls the impression they form of him, and the kinds of things he may or may not do while sustaining his performance before them. (p. 11)

In other words, he provides a framework for understanding how individuals engage in social action and why they present themselves - or perform - as they do. Goffman defines performance as "all the activity of a given participant on a given occasion which serves to influence in any way any of the participants" (p. 26). His work relies on the underlying assumption that every action is a social performance, and that these performances change depending on the social norms of the situation, the audience, and the impression the actor wishes to convey. This performance is designed not only to achieve the goals of the given action, but also to manage the impression the actor gives to others in the interaction. This idea of "image management" guides much of Goffman's work.

\section{Impressions We Give (Off)}

Goffman explains that there are two distinct modes of communication: impressions we give, and impressions we give off. The impressions we give are those that we purposely convey through the language we use in a given situation. The key concept in impressions we give is intention. This type of communication is always intentional. In contrast, impressions we give off can be either intentional or unintentional. Impressions we give off are the non-verbal communications and actions that take place in a social interaction; these impressions we give off may convey a different impression or message which expresses some aspect of the actor that is not or cannot be communicated verbally. In Goffman's analysis, when the impressions we give and the impressions we give off are in alignment with each other, 
symmetry occurs. Conversely, asymmetry occurs when verbal communications and actions or non-verbal communications convey two disparate expressions.

\section{Fronts}

Another central concept of Goffman's analysis is the idea of front. According to Goffman (1959), front can be described as "part of the individual's performance, which regularly functions in a general and fixed fashion to define the situation for those who observe the performance" ( $p$. 32). This is the façade that individuals present to provide the parameters of situation for the audience. The situation is also defined by the others in the interaction, regardless of their role, in reaction to the initially projected front. Generally, the interaction is defined by all parties in a similar way, so that "open contradictions" do not occur (p. 20). Goffman refers to this tacit agreement as a "working consensus" (p. 21). An extension of this is the idea of dramatic realization, in which actors highlight aspects of the performance that confirm what they wish to convey.

There are several components of front that help to define a given situation. First, the setting provides the "scenery" and the "stage props" that set the scene for the performance. Second, appearance and manner serve to indicate social status and the expected role of the actor, respectively. Different routines can employ the same front; moreover, fronts can become institutionalized, creating established roles that are selected by actors, not created (p. 38).

\section{Regions and Stages}

In creating a front and defining a situation, actors must acknowledge the audience for the interaction, and adapt their actions accordingly. The audience is situated in what Goffman calls a region - a "place that is bounded to some degree by barriers to perception" (p. 109). Goffman divides regions into front, back, and off "stage," classified as such by the position of the actor or team of actors in relation to the audience. On the front stage, actors and teams are attempting to foster a particular impression. On the back stage, actors or teams are contradicting the official impression 


\section{Bingham-New Institutionalism in Everyday Life}

conveyed on the front stage as a matter of course (p. 114). The off stage presents yet another region, in which the audience may be 'segregated' so as to allow distinct performances curated for distinct audiences. These concepts provide a perspective from which to interpret the actions of individuals and teams in context. In each region, both actors and audiences are easily identified and categorized, enabling the practice of impression management.

When Goffman published The Presentation of Self in Everyday Life, individual efforts were seen as leading to organizational rationality. Further, organizations were embedded in local context and relied on local actors. The institutions in which individuals and organizations operated relied on those individuals to make rational choices in their own interest or to act out of a sense of obligation (Selznick, 1949). In schools, for example, teachers could be relied on to conform to traditional teaching practices in the interest of maintaining professional respect, and fulfilling their obligation to provide all students with an education. Additionally, schools were more subject to local control, and operated in response to local needs, rather than being shaped by larger institutional priorities. This view of institutions - the "old institutionalism"- represented a view which allowed for the compartmentalization of different parts of life (e.g. work and leisure). However, as time progressed and theories evolved, social theorists began to recognize that individual's actions did not necessarily fit neatly into the categories of social obligation or rational choice. During this time, "new institutionalism" arose to better account for complexity in individual life, and to provide a lens of analysis for how institutions shaped the actors within, and vice versa.

\section{The New Institutionalism}

During the time that Goffman wrote The Presentation of Self in Everyday Life, the theoretical lens now known as "old institutionalism" was the prevailing perspective in institutional theory. Old institutionalism emphasized how informal interaction "deviated from and constrained aspects of formal structure' and subverted 'the organization's intended, rational mission by parochial interests"' (DiMaggio \& Powell, 1991, p. 13). Further, this old institutionalism stressed the importance of local communities and face-to-face interaction in organizations. The institutional environment was 
seen as neither playing a large role in the organization nor influencing individual behavior within the organization. Rather, the individual actors enabled and constrained the institutional structure.

Within the old institutional perspective, micro-social interactions were of vital importance. People were easily categorized within diverse organizational environments and the "the preservation of custom and precedent" (Selznick, 1949, as cited in DiMaggio \& Powell, p. 14) ensured "symbolic and functional consistency" within institutions. Roles were clear and individuals had an idea of how they were to act in different organizational contexts. In this way, the old institutionalism fit well with Goffman's analysis - the focus was on individual actions and how those actions shaped larger societal processes. Requirements for teachers, for example, were more bottom-up than top-down - the local took precedent over the larger institution.

Many years after Goffman published The Presentation of Self in Everyday Life, a revived interest in the study of institutions developed in reaction to what DiMaggio and Powell (1991) call "the behavioral revolution," in which institutions were viewed as "merely the sum of individual properties" (p. 2). In contrast with the old institutionalism, this "new institutionalism" stresses the taken-for-granted, routine nature of human action, and sees individuals as "constituted by institutions," rather than the other way around.

New institutionalism varies by discipline; however, these newly formulated approaches to institutions were responses to simplistic accounts of social processes and were united by "a common conviction that institutional arrangements and social processes matter" (DiMaggio \& Powell, 1991, p. 3). In this paper, I focus on new institutionalism in sociology and organizational analysis. As DiMaggio and Powell (1991) explained,

[The sociological] perspective emphasizes the ways in which action is structured and order made possible by shared systems of rules that both constrain the inclination and capacity of actors to optimize as well as privilege some groups whose interests are secured by prevailing rewards and sanctions. (p. 11)

This perspective provides the most suitable institutional lens for an 


\section{Bingham-New Institutionalism in Everyday Life}

update to Goffman's theory.

\section{Definitions and Assumptions}

Before exploring new institutionalist theories in depth, it is important to first define what is meant by institution. Jepperson (1991) broadly defines an institution as "an organized, established, procedure" (p. 143). More specifically, an institution represents "a social order or pattern that has attained a certain state or property... a social pattern that reveals a particular reproduction process" (p. 145). Under this definition, it is difficult to imagine individuals or organizations operating entirely outside institutions.

It is also important to note some of the major assumptions of new institutionalism. Immergut (1998) describes the three main assumptions of new institutional theory as being "that preferences or interests expressed in action should not be conflated with 'true' preferences, that methods for aggregating interests inevitably distort, [and] that institutional configurations may privilege particular sets of interests and may need to be reform" (p. 8). Similarly, DiMaggio and Powell (1991) explain that neo-institutionalism in sociology and organizational theory is comprised of

a rejection of rational-actor models, an interest in institutions as independent variables, a turn toward cognitive and cultural explanations, and an interest in properties of supraindividual units of analysis that cannot be reduced to aggregations or direct consequences of individuals' attributes or motives. (p. 8)

In contrast with old institutionalism, new institutionalism focuses on nonlocal context; the environment "penetrate[s] the organization, creating the lenses through which actors view the world and the very categories of structure, action, and thought" (p. 13). In neo-institutionalism, organizational forms and the structures and rules within them are institutionalized.

\section{Core Concepts in Neo-Institutionalism}

Several fundamental concepts are important to explore in pursuit of weaving together new institutional theory and Goffman's dramaturgical analysis; namely, the concepts of institutional myths, institutional isomorphism, and 
institutional logics.

Institutional myths. Meyer and Rowan (1991) assert that "organizations... dramatically reflect the myths of their institutional environments instead of the demands of their work activities" (p. 41). In other words, there is a chasm between the formal structures of the organization and the daily work activities therein. Institutionalized myths, such as professions (occupations that are controlled by inspection and social rules), programs (ideologies that define appropriate functions), and technologies (taken-for-granted technical procedures), become ceremonial for organizations. By adhering to institutionalized myths, organizations demonstrate legitimacy, rationality, and collective values, while also increasing their survival prospects. However, in conforming to institutionalized rules, organizations may have to sacrifice efficiency. Therefore, organizations create a gap between formal structures and institutionalized rules though the act of decoupling or the logic of confidence. These devices give organizations the opportunity to resolve conflict between rules and efficiency.

Decoupling and the logic of confidence. Meyer and Rowan (1991) detail the properties of organizations that represent the decoupling process as follows:

(1) Activities are performed beyond the purview of managers. (2) Goals are made ambiguous or vacuous. (3) Integration is avoided, program implementation is neglected, and inspection and evaluation are ceremonialized. (4) Human relations are made very important. (p. 57)

Through decoupling, organizations are able to retain the benefits of formal structure, while responding to everyday issues in a manner appropriate for the situation. As such, "organizations in an industry tend to be similar in formal structure - reflecting their common institutional origins - but may show much diversity in actual practice" (p. 58). Organizations present a front that is in alignment with institutional norms and expectations, but may not always be operationalizing that front in everyday practice. Though the concept of decoupling portrays organizations as somewhat chaotic, in reality, the daily activities are often orderly (Meyer \& Rowan, 1991, p. 58). "The confidence and good faith of their internal participants 


\section{Bingham-New Institutionalism in Everyday Life}

and their external constituents" allows the organizations to appear legitimate and useful (p. 58) while this "logic of confidence" allows organizations to resolve the conflicts between formal structure and efficiency (Meyer \& Rowan, 1991).

Institutional isomorphism. According to Hawley (1968, as cited in DiMaggio \& Powell, 1991), isomorphism is a "constraining process" that forces units that face the same set of environmental factors to resemble each other (p. 66). DiMaggio and Powell (1991), in their examination of institutional isomorphism, delineate the notion that organizations come to resemble each other, due to external pressures. The homogenization of organizations comes about as a result of individuals within the organization attempting to deal with uncertainty in a rational manner.

Expanding on Meyer and Rowan's (1991) work, DiMaggio and Powell (1991) explain that once organizations in the same category of business become an organizational field, outside forces emerge that push them toward homogeneity. These forces result in institutional isomorphism (DiMaggio \& Powell, 2000). There are three types of institutional isomorphism: coercive, in which the organization is coerced by law or politics; mimetic, in which the organizations imitate each other to reduce uncertainty; and normative, in which organizations copy others in pursuit of legitimacy (DiMaggio \& Powel1, 1991; 2000).

Institutional logics. Friedland and Alford (1991) posit that institutions such as capitalism, religion, and bureaucracy each operate from a central logic that informs the principles of a given organization, and provides orienting practices and symbols, around which individuals can develop a sense of identity. Further, these practices and symbols can be manipulated and elaborated upon by both the organizations and the individuals subject to the logics. This suggests that both rational choice and structuralist perspectives (staples of old institutionalism) should be rejected in favor of the view that institutions influence organizations and individuals, while also being shaped by them.

In The Presentation of Self in Everyday Life, Goffman (1959) views individuals' actions as something akin to ceremonial performances. These performances act as "an expressive rejuvenation and reaffirmation of the moral values of the community" (p. 45). In other words, individuals are "trained" in a sense to act in ways that represent the official values of the 
society in which the action occurs. This is certainly true for educators, for example, who are tasked with providing academic instruction alongside emotional development, and citizenship education (Labaree, 1997). Organizations, including schools, under the purview of neo-institutional theory, often behave in the same way. Given that society, both at the institutional level and at the individual level, has shifted and become more complicated, and common, official moral values are difficult to identify, Goffman's dramaturgical theory of everyday social interactions may benefit from the addition of a neo-institutional perspective - one which is suitable to analyzing lives and organizations that are less compartmentalized. As such, marrying new institutionalism and Goffman's lens of analysis may better account for the complexity of everyday life. In the next section, I examine how the core concepts of neo-institutionalism mirror some of the components of Goffman's theory of social interaction. In turn, I explore how Goffman's analysis may be expanded upon by integrating new institutional theory into his metaphorical theater.

\section{The New Institutionalism in Everyday Life}

Goffman (1959) uses the metaphor of a theater to analyze social interaction. Within this theater, he examines actors' performances in both front stage and back stage encounters and posits that their actions differ depending on the audience, and what type of impression the actors wish to convey. Through this dramaturgical metaphor, Goffman is able to present a compelling account of human action and impression management. However, Goffman never mentions the theater itself as a unit of analysis. This begs the question: what role might the theater in which the actors and audience exist play in social interaction? To explore this question, it is helpful to think of the theater in more literal terms - as an institution.

Goffman's purpose in writing The Presentation of Self in Everyday Life was to consider

the way in which the individual in ordinary work situations presents himself and his activity to others, the ways in which he guides and controls the impression they form of him, and the kinds of things he may or may not do while sustaining his performance before them. ( $\mathrm{p}$. 11) 
The same can be said of new institutionalism. There are many similarities between Goffman's work and the work of the new institutional theorists. Goffman's notions of front, image management, region, and front stage and back stage performances mirror several components of neo-institutionalism; namely, institutional myths and ceremonies, institutional isomorphism, and institutional logics.

Friedland and Alford (1991) conceive of institutions as "supraorganizational patterns of activity through which humans conduct their material life in time and space, and symbolic systems through which they categorize that activity and infuse it with meaning" (p. 232). These institutions each have a central logic - a set of guiding practices and symbolic constructions - that gives actors within in the institutions a sense of identity. Further, these organizing principles can be manipulated and expounded upon by individuals. Thus, institutional logics both shape individual action and are shaped by it. These institutional logics are similar to the guiding principles of the regions in which actors operate; each "stage" - front, back, and off - has its own guiding principles and set of symbols. However, Goffman's regions are more akin to organizations with specific organizational rules that, from a new institutionalist lens, are shaped by institutional logics. Using neo-institutionalism in conjunction with Goffman's stages and regions thus offers a third level of analysis, useful for explicating individual motivations, organizational influence, and the institutional logics which informs them all.

Goffman's notion of front - the part of the performance which serves to define the situation for observers - functions much like institutional myths and ceremonies. As Goffman (1959) notes,

A given social front tends to become institutionalized in terms of the abstract stereotyped expectations to which it gives rise, and tends to take on a meaning and stability apart from the specific tasks which happen at the time to be performed in its name. The front becomes a 'collective representation' and a fact in its own right. (p. 37)

The concept front, in other words, plays a role in constructing the formal structure, while not necessarily conforming to it. Further, a front can help to maintain stability in the same way that institutional myths do. Thus, institutional myths and the front that serves to define a social situation are related concepts that, taken together, could serve to analyze both micro- and 
macro-social interactions and could build upon Goffman's dramaturgical foundation.

Goffman's distinction between impressions we give and impressions we give off, and more specifically, the symmetry and asymmetry of the actions therein, closely resemble Meyer and Rowan's (1991) concept of decoupling. Particularly, their discussion of decoupling and the logic of confidence presents an argument similar to Goffman's, but extended to include behavior in institutions. According to Meyer and Rowan (1991), organizations try to maintain alignment between structures and activities. However, this is difficult. As such, daily activities are decoupled from the rules of the organization. In this way, decoupling helps organizations to maintain legitimacy, while also allowing for a certain amount of inconsistency, or reactionary practices, in daily activities. This has been seen over and over in education, as leaders and teacher "decouple" their practices from formal rules (e.g. Deal \& Celotti, 1980; Driscoll, 1995; Malen, Ogawa, \& Kranz, 1990; Meyer \& Rowan, 1977). Just as people employ front stage performances to reconcile the discrepancies between what they are actually doing or what they actually believe, and the impression they wish to convey to others, decoupling allows organizations and the actors therein to separate the explicit institutional rules and their daily actions. Within institutions, individuals often perform acts of decoupling in order to reconcile competing expectations, and institutional rules by which individuals cannot, or do not wish to abide (Meyer \& Rowan, 1991). This decoupling is similar to Goffman's delineation of front and back stage behavior; however, new institutionalism extends some of Goffman's ideas to behavior within institutions. In other words, neo-institutionalism supports Goffman's notions of image management and performance, but allows for the complicated nature of operating within modern institutions.

In both neo-institutionalism and Goffman's theory of social interaction, there is a reservoir of hidden background knowledge that is not made explicit. This is most easily seen in Goffman's analysis of front stage and back stage performances. As noted previously, actors adjust their performances depending on the audience for which they are performing. The front stage is where individual actors or a team communicate the particular impression they wish to convey. In the back stage, actors and teams behave differently, intentionally contradicting that which they portrayed on the front 
stage. This notion is similar to the maintenance of institutional myths by actors within an organization. As Goffman writes, "if members of a team must cooperate to maintain a given definition of the situation before their audience, they will hardly be in a position to maintain that particular impression before one another" (Goffman, 1959, p. 88). Actors' performances back stage, much like the internal workings of an organization in pursuit of efficiency, do not match the public image they wish to convey.

Finally, the concept of institutional myths in the new institutionalism seems a natural extension of the concept of idealization in dramaturgical analysis. Idealization is a process of expressing ideal standards, while concealing any action that does not align with those standards (Goffman, 1959, p. 50). In Goffman's analysis, this stands true for both the individual, and the organization. As Goffman notes,

Often we find that if the principal ideal aims of an organization are to be achieved, then it will be necessary at times to by-pass momentarily other ideals of the organization, while maintaining the impression that the other ideals are still in force. In such cases, a sacrifice is made not for the most visible ideal but rather for the most legitimately important one. (Goffman, 1959, p. 54)

Neo-institutionalism and the idea of institutional myths seem to expand upon this. Organizations seek legitimacy through the expressed maintenance of institutional structures. On the surface, both individuals and organizations maintain a front that legitimizes their actions; however, there can be, and often is, a gap between what is expressed, and what actually happens. It would seem that both individuals and organizations are subject to similar forces.

\section{An Example: Education as Theater}

Using education as an example institution demonstrates how new institutionalism in conjunction with Goffman's theories may be used to illuminate the complex actions in a well-known context - the school. New institutionalism has been used to understand school change (e.g. Burch, 2007), but there has been little application of Goffman's theoretical analysis in educational research. In this section, I provide some context of the current 
educational climate and discussion how these to theories may be applied together to understand educational change.

School practices have been shown over and over to be very difficult to change (Tyack \& Tobin, 1994). The organization of schools and general teacher practices have changed relatively little in the past 100 years (Tyack \& Cuban, 1995; Tyack \& Tobin, 1994). Indeed, most substantive educational reforms eventually regress to the norm (Tyack \& Cuban, 1995). There are several reasons for this. First, it is hard to alter the general cultural understanding of what schools should look like (Tyack \& Tobin, 1994). Teachers and parents have generally experienced "traditional" schooling and teaching practices, and are thus resistant to substantive changes because those changes do not represent what they see as being the true purpose and process of schooling. This has been demonstrated consistently in research on change more generally (e.g. Meyer \& Rowan, 1977)

In new institutional terms, schools are subject to institutional isomorphism - a "constraining process" that forces organizations that face the same set of environmental factors to resemble each other (DiMaggio \& Powell 1991, p. 66). The organizational homogenization is seen as a result of individuals within the organization trying to deal with ambiguity and uncertainty in a rational manner. Education as an institution also has institutional logics - specific guiding principles and symbolic constructions; namely, that all children should receive an education, and that that education should confer academic knowledge, as well as democratic and social knowledge to those students (Labaree, 1997). Additionally, in the current educational context, accountability, competition, and standardization present another layer of institutional logic to which schools are accountable (Bingham, 2017). Leaders', teachers', and students' experiences and practices are indelibly shaped by how these policy priorities intersect and are interpreted on the ground. These institutional logics shape how individuals within the school organization behave and how they shape their identities; however, the individuals within a school - administrators, teachers, and students - also shape how those goals are interpreted and enacted in practice (Weatherly \& Lipsky, 1977).

Complicating the issue is the fact that although all the actors in the school may be presenting the same front, these actors may also be presenting distinct performances in pursuit of giving the impression that they are 


\section{Bingham-New Institutionalism in Everyday Life}

upholding the current institutional logics of education. For example, teachers may act as if they are complying with institutional logics (e.g. state standards, standardized assessments) during professional development or classroom observations (the front stage), but still maintain their original teaching styles and objectives in everyday activities - intentionally or not (e.g. Cohen, 1990). They manage this through decoupling, or asymmetry between the impressions they give and the impressions they give off. Additionally, in the teacher's lounge (the back stage), for example, teachers may present yet another version of their teaching selves to their colleagues. In short, teachers may often engage in "audience segregation" to present different teaching philosophies and behaviors to different audiences and manage the impressions that they wish to give (or give off).

Finally, in looking at how the institution of education affects the daily activities in the school from a macro-lens, Goffman's concept of idealization can be expanded to include the "theater" as a unit of analysis. New reforms may be introduced into schools (idealized practices), but on the ground, teachers and administrators may simply conceal any behaviors that do not align with this idealized view for practice. Administrators attempt to maintain legitimacy and compliance, by projecting the view that they are exemplifying institutional ideals. At the macro-level, institutional myths and ceremonies are perpetuated to legitimate school practices and ensure survival; however, at the micro-social level, the interactions among actors in the school represent a complex mix of impression management, performance, and decoupling. Though the use of Goffman's perspective alone might shed some light on this complicated tangle of social interactions, only through the addition of a macro-level institutional lens would a researcher be able to pull back far enough to see the larger factors at play.

\section{Conclusion}

Goffman's theatrical metaphor serves him well in his analysis of everyday social interactions and processes. Actors perform differently depending on the audience, the impression they wish to convey, and the expected social norms and moral values. However, as noted in DiMaggio and Powell (1991), it is difficult to find places in which individuals are interacting outside of an 
organization or beyond the purview of an institution. It can be reasonably assumed then that institutional structure may also play a role in how actors perform in context. For this reason, exploring the presentation of self through new institutionalism allows for micro- and macro-analyses of individuals' performances. Moreover, neo-institutionalism aligns well with many of Goffman's major premises; indeed, it appears that many of the ideas of new institutionalism grew out of some of Goffman's work. Thus, including the "theater" in the analysis of social interaction may provide a useful, and compatible, perspective. As Friedland and Alford note (1991),

categories of knowledge contribute to and yet depend on the power of the institutions which make them possible. Without understanding the historical and institutional specificity of the primary categories of analysis, social scientists run the risk of only elaborating the rationality of the institutions they study, and as a result become actors in their reproduction. (p. 260)

The same might be said about the analysis of individual performances. By extending Goffman's analysis to include insights from neoinstitutionalism, researchers and theorists may be able to avoid this fate.

\section{References}

Burch, P. (2007). Educational policy and practice from the perspective of institutional theory: Crafting a wider lens. Educational Researcher, 36(2), 84-95.

Cohen, D. K. (1990). A revolution in one classroom: The case of Mrs. Oublier. Educational Evaluation and Policy Analysis, 12(3), 311-329. doi: 10.3102/01623737012003311

Deal, T. E., \& Celotti, L. D. (1980). How much influence do (and can) educational administrators have on classrooms?. The Phi Delta Kappan, 61(7), 471-473.

DiMaggio, P.J. \& Powell, W.W. (1991). The iron cage revisited:

Institutional isomorphism and collective rationality in organizational fields. In W.W. Powell \& P.J. DiMaggio (Eds.), The new institutionalism in organizational analysis. (pp. 63-82). Chicago: The University of Chicago Press. 
Driscoll, M. E. (1995). 4. 'We have the right to be different': Educational community through a neoinstitutional lens. Journal of Education Policy, 10(5), 55-68. doi: 10.1080/0268093950100506

Friedland, R. \& Alford, R.R. (1991). Bringing society back in: Symbols, practices, and institutional contradictions. In W.W. Powell \& P.J. DiMaggio (Eds.), The new institutionalism in organizational analysis. (pp. 232-263). Chicago: The University of Chicago Press.

Goffman, E. (1959). The presentation of self in everyday life. London: Penguin Books.

Immergut, E.M. (1998). The theoretical core of new intitutionalism. Politics and Society, 26(1), 5-34. doi: 10.1177/0032329298026001002

Jepperson, R.L. (1991). Institutions, institutional effects and institutionalism. In W.W. Powell \& P.J. DiMaggio (Eds.), The new institutionalism in organizational analysis. (pp. 41-62). Chicago: The University of Chicago Press.

Labaree, D. F. (1997). Public goods, Private goods: The American struggle over educational goals. American Educational Research Journal, 34(1), 39-81. doi: 10.2307/1163342

Malen, B., Ogawa, R. T., \& Kranz, J. (1990). What do we know about school-based management? A case study of the literature-A call for research. Choice and Control in American Education, 2, 289-342.

March, J. G., \& Olsen, J. P. (1983). The new institutionalism: Organizational factors in political life. American Political Science Review, 78(3), 734-749. doi: $10.2307 / 1961840$

Meyer, J. W., \& Rowan, B. (1977). Institutionalized organizations: Formal structure as myth and ceremony. American Journal of Sociology, 83(2), 340-363.

Meyer, J. W., \& Rowan, B. (1991). Institutionalized organizations: Formal structure as myth and ceremony. In W.W. Powell \& P.J. DiMaggio (Eds.), The new institutionalism in organizational analysis. (pp. 4162). Chicago: The University of Chicago Press.

Powell, W. W., \& DiMaggio, P. J. (Eds.). (2012). The new institutionalism in organizational analysis. Chicago: University of Chicago Press.

Selznick, P. (1949). TVA and the grass roots: A study in the sociology of formal organization. Berkeley: University of California Press. 
Selznick, P. (1996). Institutionalism" old" and" new". Administrative Science Quarterly, 41(2), 270-277. doi:10.2307/2393719

Tyack, D., \& Cuban, L. (1995). Tinkering towards utopia: A century of public school reform. Cambridge, MA: Harvard University Press. Tyack, D., \& Tobin, W. (1994). The "grammar" of schooling: Why has it been so hard to change? American Educational Research Journal, 31(3), 453-479. doi: 10.3102\%2F00028312031003453

Weatherly, R., \& Lipsky, M. (1977). Street-Level Bureaucrats and Institutional Innovation: Implementing Special Education Reform. Harvard Educational Review, 47(2), 171-197.

Andrea Bingham is Professor at University of Colorado, United States

Contact Address: andreajbingham@gmail.com 